\title{
Fine needle ethanol injection therapy for human pancreatic adenocarcinoma subcutaneously xenografted in nude mice
}

Pierre C Gagnon, MD, FrCPC, Marguerite Daumas, Norbert Allieres, Paul D Vincensini, MD, PhD, THIERRY PONCHON, MD, ETIENNE HOLLANDE, PHD

PC GAGNON, M DAUMAS, N Allieres, PD VINCENSINI, T PONCHON, E HOLLANDE. Fine needle ethanol injection therapy for human pancreatic adenocarcinoma subcutaneously xenografted in nude mice. Can J Gastroenterol 1993; $7(3): 311-318$.

OBJECTIVE: To examine the effects of fine needle ethanol injections on human pancreatic adenocarcinoma subcutaneously xenografted in nude mice. METHODS: Thirty-six nude mice were inoculated with CAPAN-1-3,35 human pancreatic cancer cell line. Tumour volumes were calculated from serial triaxial caliper measurements. On day 24 , three sets of two groups of six mice each were formed based on the tumour volume achieved at that time so that groups from the same set had comparable tumour volume. The first set of two groups was used as a feasibility study to determine the amount of ethanol or saline which could be safely injected into nude mice. The second set was injected on day 24 and 28 with a volume of ethanol (group 3) or saline (group 4) equivalent to $25 \%$ of the tumour volume and was sacrificed on day 31 . The tumours were excised for histological analysis and nuclear magnetic resonance relaxation time measurements. The third set was injected four times (on day 24, 28, 31 and 35) with a similar volume of ethanol (group 5) or saline (group 6) and was observed for tumour growth curves and mice survival comparisons. REsUlts: On light microscopy, ethanol-injected tumours were mostly necrotic with elongated and homogeneous cytoplasms and with condensed and chromophilic nuclei. As a result of ethanol-induced tumour necrosis, longitudinal (T1) and transverse (T2) relaxation times were significantly shorter for ethanol-injected tumours $(763 \pm 85$ and $72 \pm 16 \mathrm{~ms}$ ) compared with saline-injected ones ( $1147 \pm 75$ and $122 \pm 11 \mathrm{~ms}$ ). On day 42 , the mean tumour volume in group $5\left(392 \pm 366 \mathrm{~mm}^{3}\right)$ was significantly smaller than group $6\left(1392 \pm 331 \mathrm{~mm}^{3}\right)$. In group 5 , tumour growth was completely

Department of Digestive Diseases, Hôpital Edouard Herriot, Lyon; Laboratory of Cellular Biology, Université Paul Sabatier, Toulouse; and Laboratory of Medical and Biological

Engineering, Hôtel-Dieu, Toulouse, France

Correspondence and reprints: Dr Pierre Gagnon, Centre Hospitalier de l'Université Laval, Service of Gastroenterology, 2705, boulevard Laurier, Ste-Foy, Quebec GIV 4G2. Telephone (418) 654-2168, Fax (418) 654-2247

Received for publication April 27, 1992. Accepted September 20, 1992
ARCINOMA OF THE PANCREAS IS responsible for over 24,000 new cases of cancer and 20,000 cancer-related deaths annually in the United States (1). It currently ranks as the fourth most common cause of cancer death in men and the fifth leading cause of cancer death in women. Histologically, over $90 \%$ of carcinomas of the pancreas are moderately well-differentiated mucinous adenocarcinoma derived from the cuboidal epithelium of the pancreatic duct (2). In general, only a quarter of patients have lesions that are surgically resectable and only $10 \%$ have potentially curable disease at clinical presentation $(3,4)$. Preliminary studies on percutaneous ethanol injections of small hepatocellular carcinoma have shown promising results with tumour volume regression and significant tumour necrosis in patients who underwent subsequent surgical removal (5. 8). The potential advantages of fine needle ethanol injection therapy are its simplicity, low cost and low morbidity, with the ability to proceed to multiple sessions as needed. It might, therefore, be used in the palliative treatment of certain gastrointestinal tumours.

The effect of ethanol injections on pancreatic adenocarcinoma was inves- 
stopped from day 28 to 45 after which it started to expand again. In group 6 , tumour growth was continuous until day 56 when it reached a plateau. Sixty days after the last injection, $50 \%$ of the saline-injected mice were dead whereas all the ethanol-injected ones were still alive. CONCLUSIONS: This study shows that a series of fine needle ethanol injections had a significant effect on human pancreatic adenocarcinoma subcutaneously xenografted in nude mice.

Key Words: Human pancreatic cancer, Ethanol injection therapy, ${ }^{1} \mathrm{H}$ nuclear magnetic resonance, Nude mice

\section{Traitement par injections d'éthanol avec aiguille fine pour l'adénocarcinome humain du pancréas hétérogreffé par voie sous-cutanée sur des souris athymiques}

OBJECTIF: Observer les effets d'injections d'éthanol avec aiguille fine sur l'adénocarcinome humain du pancréas hétérogreffé par voie sous-cutanée sur les souris athymiques. MÉTHODE: 36 souris athymiques ont été inoculées avec la lignée de cellules de cancer humain du pancréas CAPAN-1-335. Le volume des tumeurs a été calculé à partir de mesures triaxiales sériées. Au jour 24, trois séries de deux groupes de six souris chacune ont été formées sur la base du volume tumoral obtenu, de sorte que les groupes d'une même série avaient des tumeurs de volumes comparables. La première série de deux groupes a été utilisée à titre d'essai de faisabilité pour déterminer la quantité d'éthanol ou de sérum physiologique qui pouvait être injectée sans danger aux souris athymiques. La deuxième série a reçu en injection aux jours 24 et 28, un volume d'éthanol (groupe 3) ou de solution saline (groupe 4) équivalant à $25 \%$ du volume de la tumeur et a été euthanasiée au jour 31 . Les tumeurs ont été excisées pour analyse histologique et le temps de relaxation a été mesuré par résonnance magnétique nucléaire. La troisième série a reçu quatre injections (aux jours 24, 28, 31 et 35) avec un volume égal d'éthanol (groupe 5) ou de solution saline (groupe 6) et a été observée à l'égard des courbes de croissance des tumeurs et des taux comparatifs de survie des souris. RÉSULTATS: À la microscopie classique, les tumeurs où fut injecté de l'éthanol se sont pour la plupart nécrosées, avec des cytoplasmes allongés et homogènes et des noyaux condensés et chromophiles. La nécrose tumorale induite par l'éthanol a donné lieu à des temps de relaxation longitudinale (T1) et transversale (T2) nettement plus courts ( $763 \pm 85$ et $72 \pm 16 \mathrm{~ms}$ ), par comparaison avec les tumeurs où avait été injectée de la solution saline $(1147 \pm 75$ et $122 \pm 11 \mathrm{~ms})$. Au jour 42 , le volume moyen des tumeurs du groupe $5(392 \pm 366$ $\mathrm{mm}^{3}$ ) était nettement plus petit que celui du groupe $6\left(1392 \pm 331 \mathrm{~mm}^{3}\right)$. Dans le groupe 5 la croissance tumorale avait complètement arrêté entre les jours 28 et 45 , après quoi elle a repris. Dans le groupe 6 , la croissance tumorale a été continue jusqu'au jour 56 où elle a atteint un plateau. nte jours après la dernière injection, la moitié ( $50 \%$ ) des souris ayant reçu de la solution saline étaient décédées, alors que toutes les souris qui avaient reçu de l'éthanol étaient encore en vie. CON. CLUSION: Cette étude démontre qu'une série d'injections d'éthanol avec une aiguille fine a produit un effet significatif sur l'adénocarcinome humain du pancréas hétérogreffés par voie sous-cutanée chez des souris athymiques.

tigated to determine whether ethanol injections can induce significant tumour necrosis. In clinical situations, there may be substantial palliative benefit from ethanol ablation of primary pancreatic tumours, which are notorious for producing pain. Ethyl alcohol exerts its toxic action through cellular dehydration followed by coagulative necrosis, and through vascular throm- bosis followed by occlusion. In the authors' laboratory, a model of subcutaneous xenotransplantation of human pancreatic cancer cells in nude mice was developed. The characteristics and growth patterns of this tumour model are well known and have been previously described (9-15). Using this in vivo tumour model of human pancreatic adenocarcinoma, the effects of fine needle ethanol injections on the tumour were compared with saline injections. Four parameters were studied for comparison: macroscopic and light microscopic analysis of the tumours with proton nuclear magnetic resonance ( ${ }^{1} \mathrm{H}$ NMR) relaxation time measurements, tumour growth curves establishment and mice survival time measurements. ${ }^{1} \mathrm{H}$ NMR relaxation time measurements were taken to study the potential use of this noninvasive imaging method in assessing treatment response by showing tumour necrosis. The aim of this animal study was to investigate the potential for future application of fine needle ethanol injections in the treatment of inoperable pancreatic adenocarcinoma.

\section{MATERIAL AND METHODS}

CAPAN-1 cell line in vitro: The CAPAN-1 cell line was isolated by Fögh in 1974 at the Sloan-Kettering Institute for Cancer Research, New York, from a liver metastasis of a pancreatic adenocarcinoma grown in a 40-year-old Caucasian man (16). This cell line was received in the Laboratory of Cellular Biology in Toulouse, France, at the 14th passage from the American Type Culture Collection, Maryland. The cell line was maintained in Roswell Park Memorial Institute (RPMI) 1640 medium (Gibco, New York) containing $200 \mathrm{U} / \mathrm{mL}$ penicillin, $0.125 \mathrm{mg} / \mathrm{mL}$ streptomycin, $0.125 \mathrm{mg} / \mathrm{mL}$ amphotericin B and supplemented with $15 \%$ fetal calf serum (Biopro, Germany). Tumour cells were grown in monolayers and maintained through successive passages by treatment with $0.125 \%$ trypsin- $0.02 \%$ EDTA. The doubling time was $20 \mathrm{~h}$. Cell cultures were regularly checked for mycoplasmic contamination.

CAPAN-1-335 cell line in vivo: The CAPAN-1-335 cell line has been maintained in the laboratory of cellular biology in Toulouse since 1986. It was obtained by dorsal subcutaneous injection of $4 \times 10^{6}$ CAPAN- 1 cells into five- to six-week-old, congenitally athymic mice, nu/nu mice (Swiss, IFFA-CREDO, France) weighing about $20 \mathrm{~g}$. Eight to 10 days following inoculation, subcutaneous tumours appeared. This in vivo 
cell line is maintained by successive passages every 60 days by dorsal subcutaneous inoculation to other nude mice of $0.5 \mathrm{~mL}$ homogeneous suspension of small tumour fragments minced with scissors and bathing in RPMI medium. It is now at its 35 th passage.

Experimental protocol: Using this in vivo tumour model of human pancreatic adenocarcinoma, the effects of fine needle ethanol injections on the tumour were compared with those of saline injections on macroscopic and microscopic changes, ${ }^{1} \mathrm{H}$ NMR relaxation time measurements, tumour growth curves and survival time. Thirty-six nude mice were inoculated with 0.5 mL CAPAN-1-335 tumour fragments as described above. During all experiments, they were kept in a pathogen-free environment at $28^{\circ} \mathrm{C}$ and given water and a standard diet ad libitum. Eight days after the inoculation, subcutaneous tumours appeared. For the establishment of growth curves, tumour size was measured in the same conditions by the same operator twice a week in all three dimensions with calipers.

Tumour volume (V) was calculated from the ellipsoid volume formula:

$$
V=\frac{4}{3} \times \pi \times \frac{\text { length }}{2} \times \frac{\text { width }}{2} \times \frac{\text { height }}{2}
$$

Twenty-four days after inoculation, three sets of two groups of six mice each were formed based on the tumour volume achieved at that time. The two groups belonging to the same set had to be homogeneous in tumour volume. To obtain such an even distribution in tumour volume between groups of the same set, the mice were classified in a descending order based on their tumour volume on day 24; the first 12 mice with the largest tumour volume were alternatively allocated to group 1 or group 2, the next 12 mice to groups 3 and 4 , and the last 12 mice with the smallest tumour volume on day 24 formed groups 5 and 6 . The mean tumour volume $( \pm \mathrm{SD})$ on day 24 was $2224 \pm 804$ and $2219 \pm 766 \mathrm{~mm}^{3}$ respectively, for groups 1 and 2; $870 \pm 169$ and $858 \pm 171 \mathrm{~mm}^{3}$, respectively, for groups 3 and 4 ; and $345 \pm 176$ and $351 \pm 150$ $\mathrm{mm}^{3}$, respectively, for groups 5 and 6. In each set, one group (groups 1, 3 and 5) was treated with fine needle dehydrated ethanol injections while the other one (groups 2, 4 and 6) was treated with saline injections (normal $0.9 \%$ saline). Day 24 was chosen to begin the injections because the tumours at that time were thought to be large enough to allow for safe and easy injections. All injections were performed by the same operator, at the same time and in similar conditions (eg, using a $25 \mathrm{G} 5 / 8$ needle). The volume of ethanol or saline to be given was injected slowly in four equidistant points with the needle about $0.5 \mathrm{~cm}$ deep in the tumour while a second operator was holding the mouse in a fixed position.

The first set of two groups (groups 1 and 2) was used as a feasibility study aiming to determine if it was possible to inject ethanol subcutaneously to nude mice without killing them from ethanol overdose and to see how easily ethanol diffuses in such a tumour without back-diffusion along the needle tract to decide on the amount of ethanol or saline to be injected in the other groups. Two mice from group 1 were injected with a volume of ethanol corresponding to $50 \%$ of their tumour volume as measured just before the treatment session $(1.6$ and $0.8 \mathrm{~mL}$, respectively). This was associated with rapid mice death due to ethanol overdose and to significant back-diffusion of ethanol along the needle tract. The four other mice belonging to group 1 were injected with a volume of ethanol corresponding to $25 \%$ of their tumour volume; two more mice died from ethanol overdose (having received 0.4 and $0.8 \mathrm{~mL}$ of ethanol, respectively) whereas the two others (having received 0.4 and $0.3 \mathrm{~mL}$ of ethanol, respectively) survived. By comparison, all mice in group 2 treated with equivalent volume of saline survived. Based on this feasibility study, the mice from all the other groups (groups 3 to 6 ) were injected with a volume of ethanol or saline corresponding to $25 \%$ of the tumour volume as measured just prior to injection. However, in order to avoid a lethal ethanol overdose, a maximal

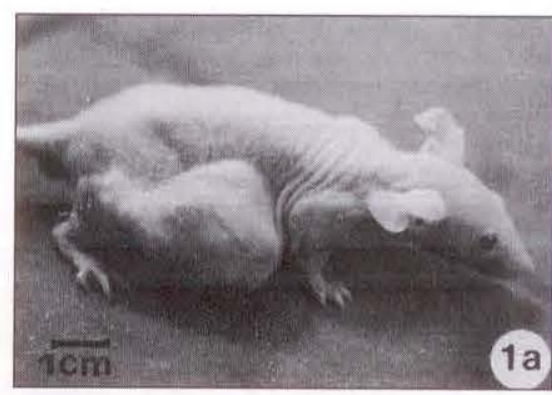

Figure 1a) Macroscopic effects of saline injections. A mouse belonging to group 6 on day 36 after tumour inoculation is shown. The tumour has been injected with saline four times on days $24,28,31$ and 35 . The volume of saline given corresponded to $25 \%$ of tumour volume and was injected in four equidistant points within the tumour

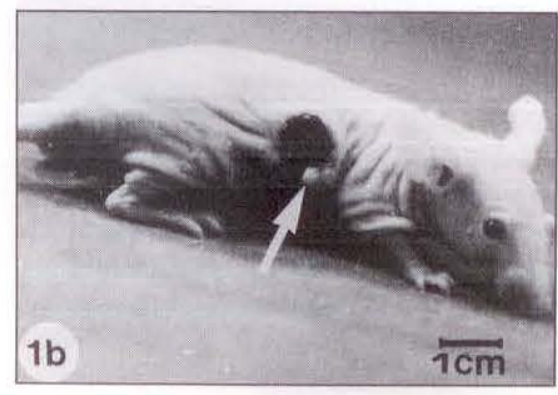

Figure 1b) Macroscopic effects of ethanol injections. A mouse belonging to group 5 on day 36 after tumour inoculation is presented. The tumour has been injected with ethanol four times on days 24, 28, 31 and 35. The volume of ethanol given corresponded to $25 \%$ of tumour volume and was injected in four equidistant points within the tumour. Compared with Figure la, there is a striking regression of the tumour volume and the presence of small tumoral nodules at the periphery of the necrotic centre (arrow)

amount of $0.3 \mathrm{~mL}$ ethanol or saline was administered when the tumour volume exceeded $1200 \mathrm{~mm}^{3}$.

The second set of two groups (groups 3 and 4) was treated twice, on day 24 and 28 after inoculation. Group 3 received ethanol and group 4 received saline. Three days after the last treatment session, on day 31 , all mice from both groups were sacrificed by cervical dislocation; their subcutaneous tumours were excised and submitted to microscopic analysis and to ${ }^{1} \mathrm{H}$ NMR relaxation time measurements. This second set allowed the study of the acute effects of two ethanol injections spaced by four days. For light microscopy, fragments of tumours were fixed 


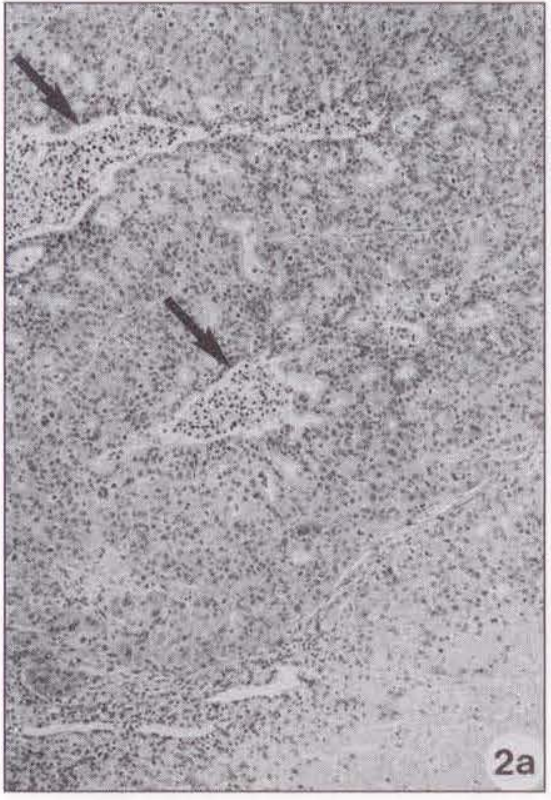

Figure 2a) Microscopic effects of saline injections are shown. Tumour of a mouse belonging to group 4 (treated twice with saline on days 24 and 28 after tumour inoculation). Mice were sacrificed on day 31 ; tumours were excised, fixed in Boulin's liquid, and stained with hematoxylin and eosin. The tumoral proliferating zones are conspicuous while the necrotic ones are poorly developed (arrows) (X88)

in Bouin's liquid and stained with hematoxylin and eosin. For ${ }^{1} \mathrm{H}$ NMR analysis, fragments of tumour were rapidly packed in NMR tubes $(8 \mathrm{~mm}$ inside diameter) and kept on crushed ice as recommended by Beall (17). The ${ }^{1} \mathrm{H}$ NMR measurements were performed with a Bruker CP 100 spectrometer (Karlsruhe, Germany) in Fourier transform mode, operating at $60 \mathrm{MHz}$ (magnetic field $=1.4 \mathrm{~T}$ ). The longitudinal relaxation time, $\mathrm{T} 1$, and the transverse relaxation time, $\mathrm{T} 2$, were determined using the inversion recovery $\left(180^{\circ}-\mathrm{T}\right.$. $90^{\circ}$ ) pulse sequence and the spin-echo method of Meiboom-Gill-Carr and Purcell $\left(90^{\circ}-\left[\mathrm{T}-180^{\circ}\right] \mathrm{n}\right)(18)$.

The third set of two groups (groups 5 and 6) was used for comparison in tumour growth and survival time. Group 5 was treated with ethanol while group 6 was treated with normal saline. Both groups were treated four times: on days 24, 28, 31 and 35. Each time the volume of ethanol or normal saline given corresponded to $25 \%$ of the tumour volume as measured just before treatment. Again, the maximal volume

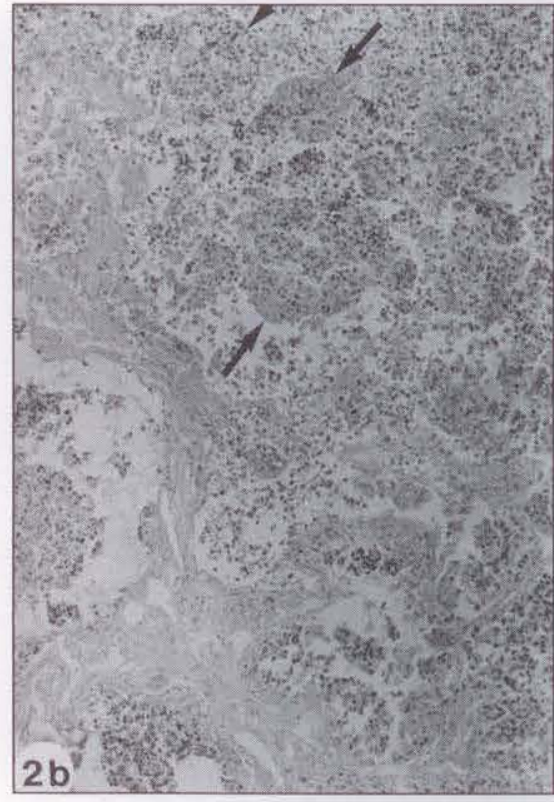

Figure 2b) Microscopic effects of ethanol injections are depicted. Tumour of a mouse belonging to group 3 (treated twice with ethanol on days 24 and 28 after tumour inoculation). Mice were sacrificed on day 31; tumours were excised, fixed in Boulin's liquid, and stained with hematoxylin and eosin. Residual areas of tumour cells (arrows) are composed of degenerating cells with pycnotic nuclei ( $\times 88$ )

given per session was $0.3 \mathrm{~mL}$ if the tumour volume exceeded $1200 \mathrm{~mm}^{3}$. The injections were performed by the same operator in a similar fashion as described for groups 3 and 4. Following the fourth treatment session, mice from each group were simply observed in similar conditions without any further treatment; their tumours were measured twice weekly for growth curves comparisons and their survival time was established.

Statistical analysis: All descriptive statistics are expressed as mean $\pm S D$. Comparisons in means were performed with the two-sample Wilcoxon test. Lifetable survival curves were established using the Kaplan-Meier method (19) and comparisons in survival time were done using the Log-rank test. $\mathrm{P}<0.05$ was considered statistically significant.

\section{RESULTS}

Macroscopic and microscopic effects of ethanol injections: Figures $1 \mathrm{la}$ and $1 \mathrm{~b}$ show two nude mice 36 days after subcutaneous inoculation of human pancreatic adenocarcinoma. Figure 1a represents a mouse belonging to group 6 which has been injected four times with saline and Figure $1 \mathrm{~b}$ represents a mouse from group 5 treated with ethanol injections. The tumour treated with ethanol has almost completely disappeared leaving a scarring or crusted area in lieu of the tumour with a peripheral rim consisting of small tumoral nodules (Figure $1 \mathrm{~b}$, arrow). In this nude mouse model, the tumour usually is indurated and firm. During ethanol injection, immediate blanching at the injection point was generally observed and it was noted that the volume injected did not diffuse well into the tumour bed, but was usually limited and circumscribed to a small area around the needle tip. Forcing a larger amount of ethanol to enter the same injection point often resulted in alcohol flowing back along the needle tract or diffusing around, instead of within, the tumour.

On light microscopy, the tumour treated with saline injections did not undergo any significant change. The proliferating areas consisting of multiple small tumoral nodules were still present and adenoid structures were often seen (Figure 2a). In xenografted tumours, bands of connective tissue were rare and necrotic areas poorly developed (Figure 2a, arrow). By contrast, in the tumour treated with ethanol injections, tumoral tissue was largely destroyed and replaced by necrosis (Figure 2b). On some slides, there were still areas of pycnotic cells corresponding to former tumoral nodules (Figure $2 \mathrm{~b}$, arrow). Similarly, connective tissue was also destroyed. At the periphery of the tumours injected with ethanol, proliferating zones identical to those described for tumours injected with saline could be identified; they corresponded to the peripheral tumoral nodules surrounding a central necrotic area.

Figure 3 shows the histological aspect of a tumour injected with saline. The nuclei do not depict any alteration and are similar to the nuclei appearance of untreated tumours. The salinetreated tumours showed numerous cells undergoing mitosis (Figure 3, arrows).

Soon after ethanol injections, however, cellular aspects changed. Cells within the proliferating areas presented 
with an elongated cytoplasm - very homogeneous - and with an amorphous and very chromophilic nucleus. In many cells, the nuclei contained large amounts of condensed chromatin. In later stages following ethanol injections, these nuclei were surrounded by necrotic material indicating complete cytoplasmic destruction. Similarly, the chromosomes from mitotic cells exposed to ethanol were degenerated and very condensed (Figure 4, arrow). The cellular aspect was similar to the one produced by a bad alcohol fixation for histological analysis.

Effects of ethanol injections on ${ }^{1} \mathrm{H}$ NMR relaxation time: On day 31 , three days after the second session of injections, fragments of tumour from group 4 (saline injections) and group 3 (ethanol injections) were submitted to ${ }^{H}$ NMR relaxation time measurements (Figure 5). The mean longitudinal relaxation time $T 1$ was $1147 \pm 75 \mathrm{~ms}$ for tumours injected with saline compared with $763 \pm 85 \mathrm{~ms}$ for those injected with ethanol $(\mathrm{P}<0.05)$. Similarly, the mean transverse relaxation time $\mathrm{T} 2$ was $122 \pm 11 \mathrm{~ms}$ for saline-injected tumours compared with $72 \pm 16 \mathrm{~ms}$ for ethanolinjected ones $(\mathrm{P}<0.05)$. Thus, the necrotic changes induced by ethanol as observed on light microscopy were associated with a consistent shortening of the $\mathrm{T} 1$ and $\mathrm{T} 2$ relaxation time on ${ }^{1} \mathrm{H}$ NMR.

Effects of ethanol injections on tumour growth curves and survival: The growth curves of tumours from group 3 (ethanol-injected) and group 4 (salineinjected) are shown in Figure 6. On day 28 , two of the six mice from group 3 were injected with $0.3 \mathrm{~mL}$ ethanol because their tumour volumes were over $1200 \mathrm{~mm}^{3}$ (1500 and $1686 \mathrm{~mm}^{3}$, respectively) whereas three of the six mice from group 4 were injected with $0.3 \mathrm{~mL}$ saline for the same reason (tumour volume of 1822, 1900 and 2010 $\mathrm{mm}^{3}$, respectively). All other mice from both groups were injected with a volume of ethanol or saline corresponding to $25 \%$ of their tumour volume achieved on day 24 and 28. From the day of inoculation until day 24 , tumour growth curves from both groups were identical with a mean tumour volume

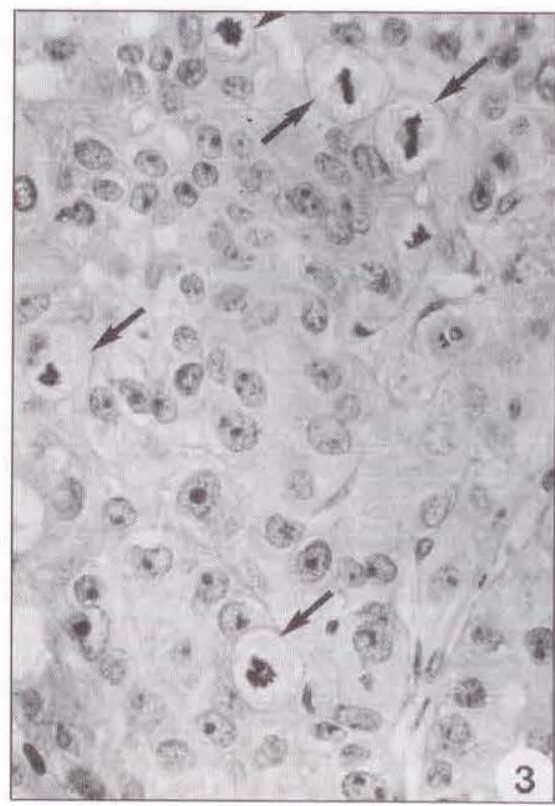

Figure 3) Microscopic effects of saline injections are shown. A comparative histological structure of a xenografted pancreatic tumour injected with saline is depicted; it is a greater magnification of Figure $2 a$ ( $\times 560)$. The typical aspect of tumour cells and nuclei within a proliferating area is seen. Cellular mitoses are numerous (arrows)

on day 24 of $870 \pm 69$ and $899 \pm 157 \mathrm{~mm}^{3}$ for groups 3 and 4 , respectively. Following the first injection, growth curves started to diverge immediately; tumours injected with saline continued to grow while tumours injected with ethanol underwent a plateau and started to decrease in volume. Three days after the second session of injections, the mean tumour volume was $858 \pm 171$ and $2176 \pm 735 \mathrm{~mm}^{3}$ for groups 3 and 4 , respectively $(\mathrm{P}<0.05)$.

Mice from groups 5 and 6 underwent four sessions of injections (on days 24, 28,31 and 35) and were then observed in similar conditions for comparisons in tumour growth and mice survival. Group 5 received ethanol and group 6 received saline. In this set, all mice from both groups were injected with a volume of ethanol or saline corresponding to $25 \%$ of their tumour volume (which was lower than $1200 \mathrm{~mm}^{3}$ for all of them on each treatment day). Again, the tumour growth curve was similar between the two groups up to day 24 . On day 24 - just before the first treatment session - the mean tumour

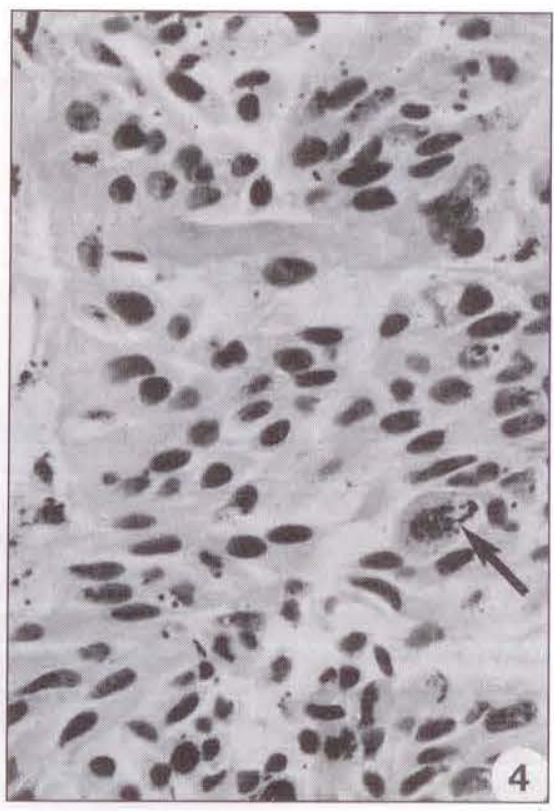

Figure 4) Microscopic effects of ethanol injections are shown. A comparative histological structure of a xenografted pancreatic tumour injected with ethanol is depicted; it is a greater magnification of Figure $2 b(\times 560)$. The peculiar aspect of cells exposed to ethanol with homogeneous cytoplasm and pycnotic nuclei are visible and there is degenerated chromosome within cells in mitosis at alcoholization (arrows)

volume was $345 \pm 176$ and $360 \pm 149$ $\mathrm{mm}^{3}$ for groups 5 and 6 , respectively. On day 42 , one week after the last treatment session, the mean tumour volume was $392 \pm 366$ and $1392 \pm 331$ $\mathrm{mm}^{3}$ for groups 5 and 6 , respectively $(\mathrm{P}<0.05)$. Tumour growth curves started to diverge almost immediately following the first session of injections (Figure 7). The growth of tumours from group 6 (saline injections) was continual until day 56 when it reached a plateau. By comparison, tumours from group 5 (ethanol injections) stopped growing almost immediately and remained stationary from day 28 to 45 . On day 45, 10 days after the last ethanol injections, tumour volume started to expand again. The difference in mean tumour volume between the two groups remained statistically significant $(\mathrm{P}<0.05)$ from day 42 to 63.

Life-table survival curves using the Kaplan-Meier method and comparing group 5 (ethanol or treated group) with group 6 (saline or control group) are shown in Figure 8. Up to day 30 after the last session of injections (corre- 


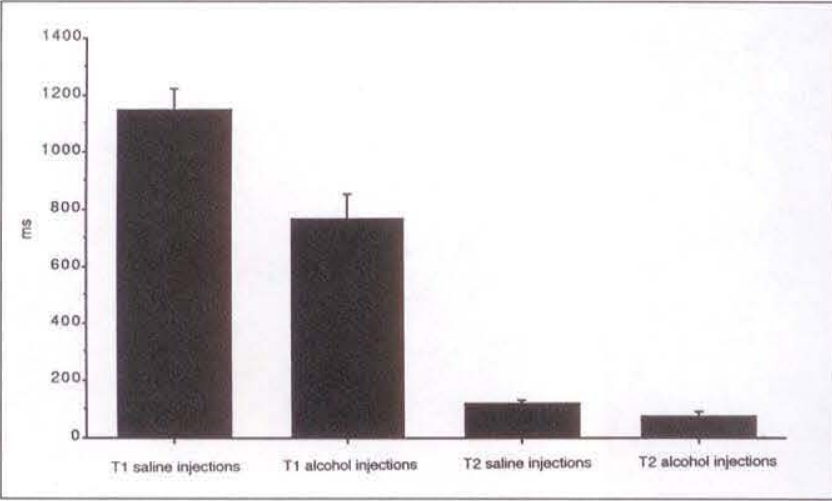

Figure 5) Proton nuclear magnetic resonance $\left({ }^{1} \mathrm{H}-\mathrm{NMR}\right)$ longitudinal (T1) and transwerse (T2) relaxation time measurements in tumours treated with saline injections compared with tumours treated with ethanol injections. Results are mean $\pm S D$ of six mice. The analysis was done on day 31 on tumour fragments from group 4 (saline injections) and group 3 (ethanol injections), three days after the second session of injections

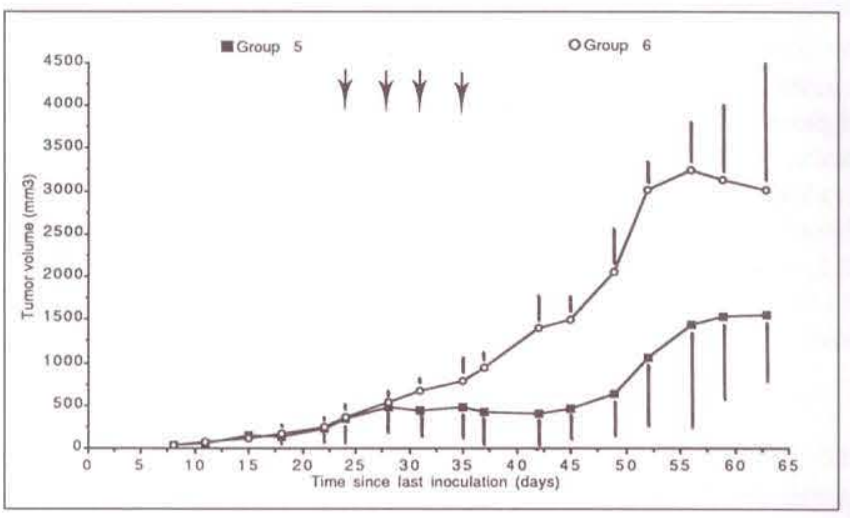

Figure 7) Tumour growth curves of mice from groups 5 and 6 are shown; each group was treated four times, on days 24, 28, 31 and 35 after inoculation (arrows). Group 5 received ethanol injections and group 6 received saline injections. Results are mean $\pm S D$ of six mice. Effects of alcoholization on tumour growth curve compared with saline injections are shown

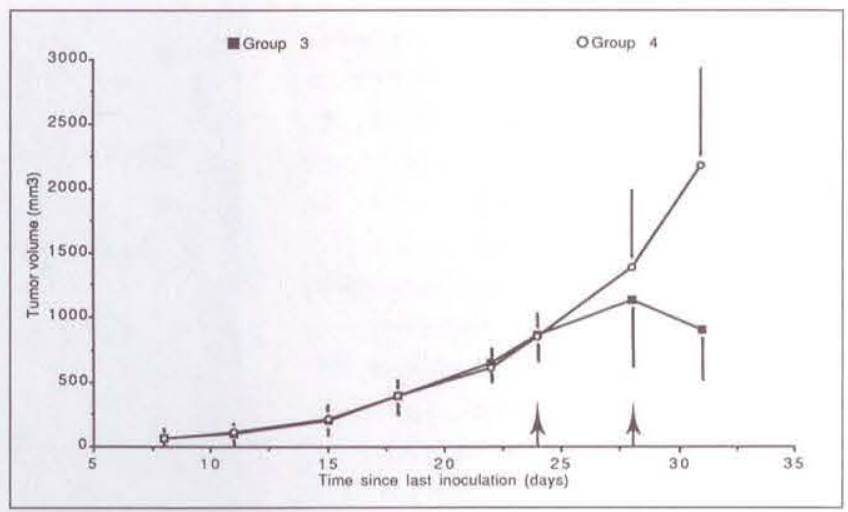

Figure 6) Tumour growth curves of mice from groups 3 and 4 are presented; each group was treated twice, on day 24 and 28 after inoculation (arrows). Group 3 received ethanol injections and group 4 received saline injections. Results are mean $\pm S D$ of six mice. Effects of alcoholization on tumour growth curve compared with saline injections are shown

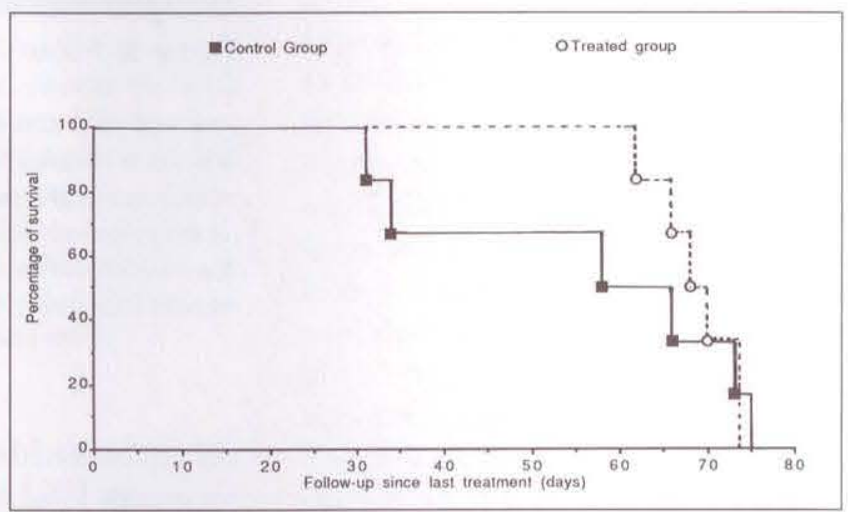

Figure 8) Survival curve of treated group compared with control group is shown. Life-table survival curves of mice from group 5 (treated group) and group 6 (control group) are presented. Each group was treated four times, on days $24,28,31$ and 35 after inoculation. Group 5 received ethanol injections and group 6 received saline injections. The abscissa represents days of follow-up since last treatment sponding to day 65 after inoculation) all mice from both groups were still alive. The first death occurred in control group 6, 31 days after the last session of injections. The other mice from group 6 died on days $34,58,66,73$ and 75 , respectively. By day 59 of follow-up, $50 \%$ (three of six) of the mice injected with saline were dead whereas the six mice injected with ethanol were still alive $\left(\chi^{2}=3.35\right.$, not significant $)$. The first mouse belonging to treated group 5 died on days 62 , and the others died on days $66,68,70,73$ and 73 , respectively. Mice from treated group 5 survived $68.7 \pm 4.3$ days after the last treatment compared with $56.2 \pm 19.3$ days for control group 6.

\section{DISCUSSION}

This study shows that a series of fine needle ethanol injections has a striking effect on CAPAN-1-335 pancreatic adenocarcinoma subcutaneously xenografted in nude mice. The volume of ethanol injected per session was fixed at $25 \%$ of the tumour volume with a maximum of $0.3 \mathrm{~mL}$ to avoid mouse death due to ethanol overdose. This provision on the volume of injection could potentially have introduced a bias between the groups. However, only two mice from group 3 and three from group 4 received $0.3 \mathrm{~mL}$ ethanol or saline on day 28; all other mice from groups 3 to 6 were injected with a volume of ethanol or saline corresponding to $25 \%$ of their tumour volume as measured just before the injection. The authors believe that the groups from the same set were fully comparable; the tumour volumes and growth curves before beginning the injections were wellmatched and the only variable between groups was the nature of injections.

The volume of ethanol was injected in four equidistant points within the tumour mass and produced immediate blanching of the tumour at the injection point followed by necrosis and sloughing. Ethanol does not diffuse easily within this type of tumour, but forcing a larger amount of ethanol to enter the same injection point often resulted in ethanol flowing back along the nee- 
dle tract or diffusing around, instead of within, the tumour. It appears that injecting a given volume of ethanol in multiple points (instead of a unique central injection) would give better results. This observation implies the requirement for multiple sessions of injections to reach the tumour bed with ethanol completely. It is possible that injecting a larger amount of ethanol in multiple points during the same session, such as $50 \%$ of tumour volume, could also result in better tumour impingement. We are presently studying these hypothesis in new experiments, starting the injections at a lower tumour volume to avoid mouse death from ethanol overdose.

Compared with saline, ethanol produced immediate and striking local tumour destruction (as shown on light microscopy). Following ethanol injections, tumoral tissue is partly destroyed; the malignant cells first appeared fixed by ethanol, which seems to precipitate or denaturate the cellular proteins. Such findings are mostly found in the tissue along the needle tract. The fixed malignant cells then undergo progressive degeneration and become indistinguishable a few days after the injections. This cellular degeneration seems to trigger connective tissue production since a significant connective tissue reaction was found surrounding the tumoral areas exposed to ethanol. Therefore, fol-

ACKNOWLEDGEMENTS: Dr Gagnon is the recipient of a LATEMA research grant from 'Les Laboratoires LTM LATEMA', Paris, France.

\section{REFERENCES}

1. Cello JP. Carcinoma of the pancreas. In: Sleisenger MH, Fordtran JS, eds. Gastrointestinal Disease, vol 2, 4th edn. Philadelphia: WB Saunders Company, 1989:1872-84.

2. Kissane JM. Carcinoma of the exocrine pancreas: Pathologic aspects. J Surg Oncol 1975;7:167-73.

3. Moosa AR. Pancreatic cancer: approach to diagnosis, selection for surgery and choice of operation. Cancer 1982;50:2689-98.

4. Applequist P, Viren M, Minkkinen J, et al. Operative finding, treatment, and prognosis of carcinoma of the lowing ethanol injections, many tumoral areas are replaced by necrotic tissue infiltrated by fibroblasts.

The significant shortening of the ${ }^{1} \mathrm{H}$ NMR relaxation time $\mathrm{T} 1$ and $\mathrm{T} 2$ found in the tumours injected with ethanol may be the consequence of these histological changes; these relaxation times do not correspond to normal pancreatic adenocarcinoma but to a fibroblastic tissue associated with necrotic tumoral tissue. These T1 and T2 values must be compared with those found in untreated CAPAN-1 tumours of different ages as published previously (13). For mice submitted to $\mathrm{H}$ NMR analysis at various times after inoculation (39 to 140 days), mean values are $987 \pm 90 \mathrm{~ms}$ for T1 and $85 \pm 9 \mathrm{~ms}$ for T2. Furthermore, it should be noted that no significant variation in $\mathrm{T} 1$ and $\mathrm{T} 2$ values were found between tumours of different ages. Thus, the necrotic changes induced by ethanol as observed on light microscopy were associated with a consistent shortening on the T1 and T2 relaxation time on ${ }^{1} \mathrm{H}$ NMR.

\section{CONCLUSIONS}

Tumour growth curves were significantly and rapidly altered by ethanol injections; the tumour stopped growing and decreased in volume as long as sessions of ethanol injections were given. Furthermore, a trend towards prolonged survival was also noted in mice which received four series of ethanol

pancreas: An analysis of 267 cases. J Surg Oncol 1983;23:143-51.

5. Shiina S, Yasuda H, Muto H, et al. Percutaneous ethanol injection in the treatment of liver neoplasms. Am J Radiol 1987;149:949-52.

6. Livraghi T, Salmi A, Bolondi, et al. Small hepatocellular carcinoma: Percutaneous alcohol injection Results in 23 patients. Radiology 1988;168:313-7.

7. Sheu JC, Huang GT, Chen DS, et al. Small hepatocellular carcinoma: Intratumour ethanol treatment using new needle and guidance systems. Radiology 1987;163:43-8.

8. Shiina S, Niwa Y, Hata Y, et al. Percutaneous ethanol injection therapy for liver tumours. Dig Dis Week 1990:A257. (Abst)

9. Kyriasis AP, Kyriasis AA, Scarpelli DG, Fögh J, Rao S, Lepera R. Human injections compared with saline injections. It is not known if a different schedule of ethanol injections or if injecting a larger volume of ethanol per session might result in a complete tumour eradication in this animal model. Further experiments are needed to determine whether ethanol injection therapy should be restricted to palliative control of tumour extension and to establish optimal injection schedules.

To what extent this animal study could predict tumour response to ethanol injections in clinical situations is unknown. Subcutaneous tumours are easy to inject with precise positioning of the needle tip. Pancreatic adenocarcinomas in humans are often infiltrative and less accessible, and complete tumoral destruction with fine needle ethanol injection therapy is unrealistic. However, if it can slow down tumoral progression, this therapy might be considered as a potential palliative treatment in certain situations, especially for the palliative control of the severe pain associated with that cancer. Percutaneous ethanol injection therapy of liver tumours, as well as ethanol-induced tumour necrosis, to palliate dysphagia in patients with inoperable esophagogastric cancer are being reported with promising results $(5-8,20)$. The nude mouse model is an interesting research tool which could later lead to an optimalization of this new tumoricidal technique.

pancreatic adenocarcinoma line CAPAN-1 in tissue culture and in nude mouse. Am J Pathol 1982;106:250-60.

10. Kyriasis AP, Kyriasis AA, Sternberg CN, Sloan NH, Loveless JJ.

Morphological, biological, biochemical and karyotypic characteristics of human pancreatic ductal adenocarcinoma CAPAN-2 in tissue culture and the nude mouse. Cancer Res 1986;46:5810-5.

11. Hollande E, Trocheris De St-Front V, Louet-Hermitte P, Bara J, Pequignot J. Differentiation features of human pancreatic tumour cells maintained in nude mice and in cultures: Immunocytochemical and ultrastructural studies. Int J Cancer 1984;34:177-85.

12. Levrat JH, Palevody C, Daumas M, Ratovo G, Hollande E. Differentiation of the human pancreatic 
adenocarcinoma cell line (CAPAN-1)

in culture and co-culture with fibroblasts dome formation. Int ] Cancer 1988;42:615-21.

13. Murat C, Esclassan J, Daumas M, et al. Enhanced membrane phospholipid metabolism in human pancreatic adenocarcinoma cell lines detected by low-resolution ${ }^{1} \mathrm{H}$ nuclear magnetic resonance spectroscopy. Pancreas 1989;4:145-52.

14. Marincola FM, Drucker BJ, Siao DY, Hough KL, Holder WD. The nude mouse as a model for the study of human pancreatic cancer. J Surg Res 1989;47:520-9.

15. Lesser ML, Braun HI, Helson L.

Statistical methods for measuring and comparing treatment efficacies: Application to nude mice experimentation. Exp Cell Biol 1980;48:126-33

16. Fogh J, Wright WC, Loveless LD. Absence of HeLa cell contamination in 169 cell lines derived from human tumours. J Natl Cancer Inst 1977;58:209-14.

17. Beall PT. Practical methods for NMR sample handling. Magn Reson Imaging 1982;1:165-81.

18. Meiboom S, Gill D. Modified spin echo method for measuring nuclear relaxation times. Rev Sci Instr 1958;29:688-94.

19. Pocock SJ. Clinical Trials. A Practical Approach. Avon: John Wiley \& Sons Ltd, 1983:211-33.

20. Payne-James JJ, Spiller RC, Misiewicz JJ, Silk DBA. Use of ethanol-induced tumour necrosis to palliate dysphagia in patients with esophagogastric cancer. Gastrointest Endosc 1990;36:43-6. 


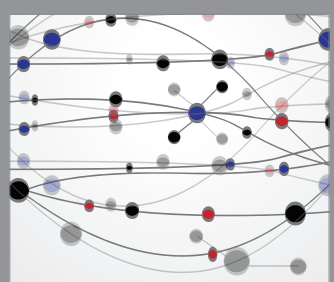

The Scientific World Journal
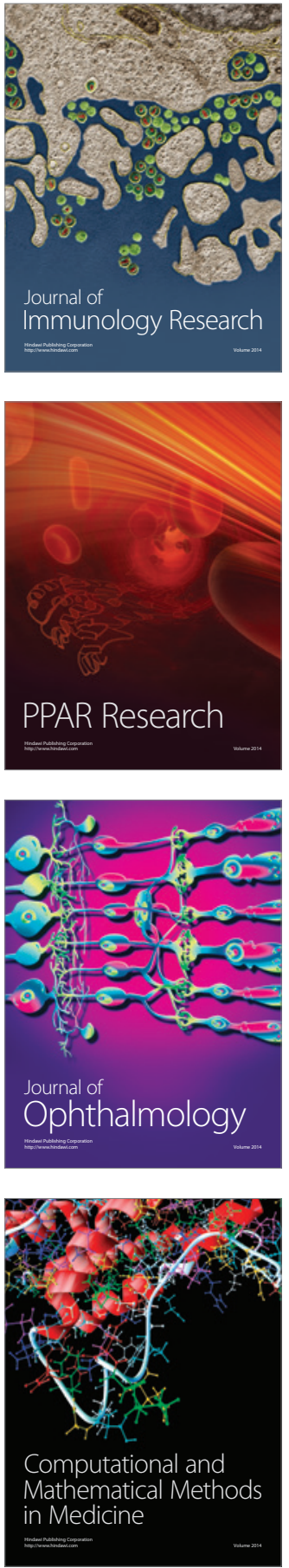

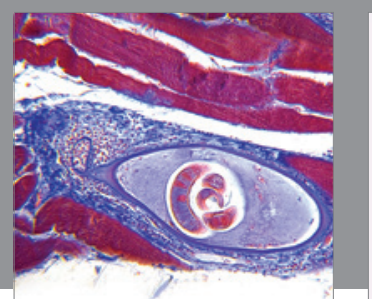

Gastroenterology Research and Practice

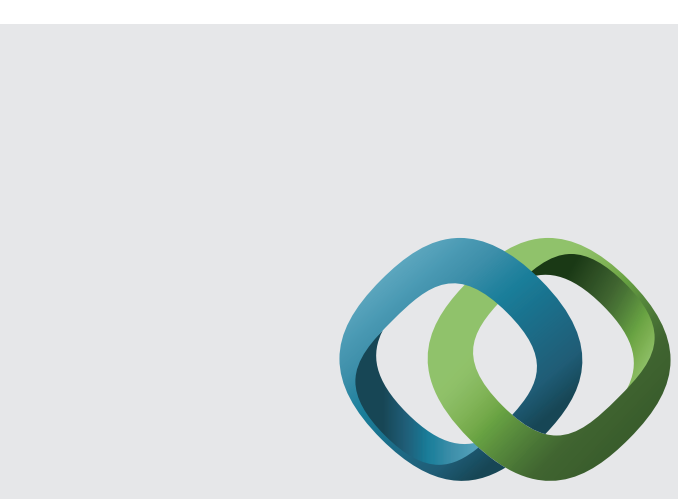

\section{Hindawi}

Submit your manuscripts at

http://www.hindawi.com
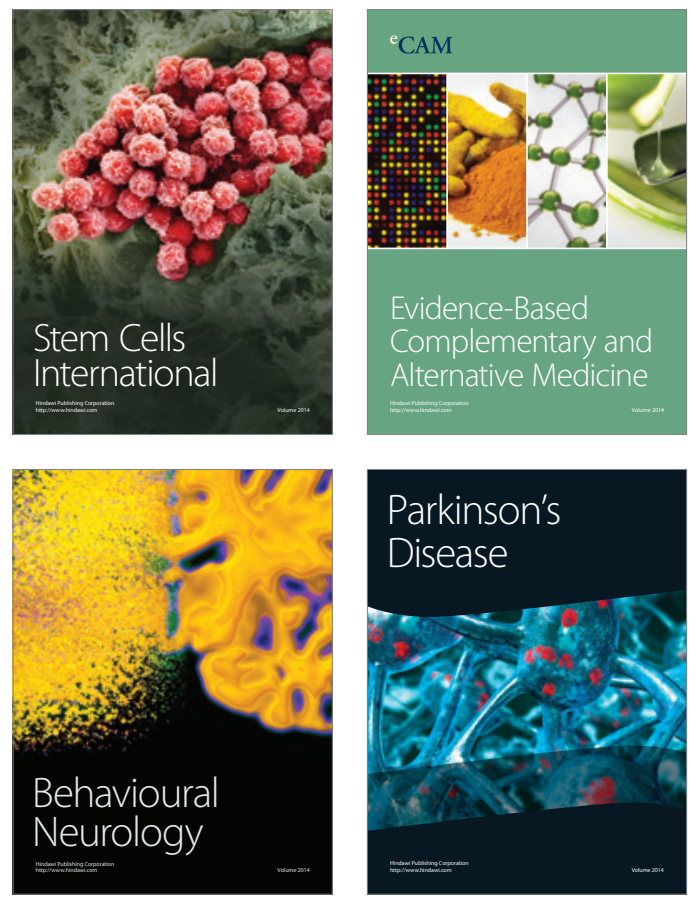
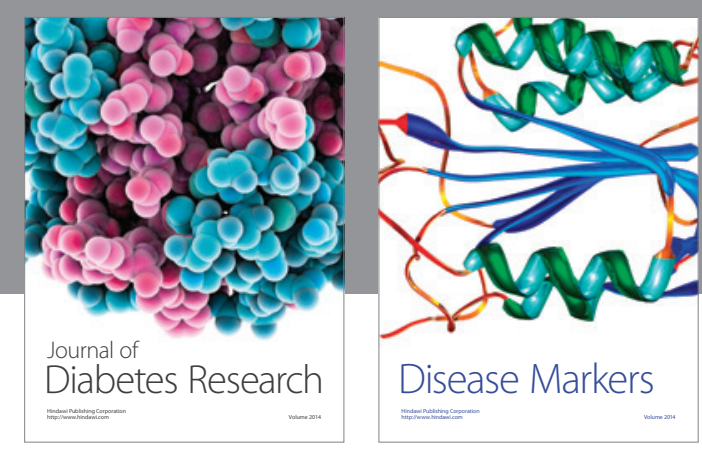

Disease Markers
